\title{
De corpo e alma na margem: catolicismo, santidade e medicina no Norte de Portugal (c. 1900 - c. 1950)*
}

\author{
Tiago Pires Marques \\ Cermes3/Universidade Paris Descartes \\ Paris, França \\ Centro de Estudos de História Religiosa (Universidade Católica Portuguesa) \\ Lisboa, Portugal \\ tiagopmarques@gmail.com
}

\begin{abstract}
RESUMO
Num primeiro olhar, a personalidade religiosa da beata Alexandrina Maria da Costa surge como estranha e desconcertante. Este artigo propõe um exercício de compreensão histórica e antropológica que reduz essa estranheza. Sustenta-se que este caso reflete a história de uma comunidade com uma identidade religiosa forte, onde um catolicismo devocional convivia com investidas clericais visando promover uma subjetividade espiritual. Ao mesmo tempo, a medicina e a psiquiatria forneceram novas grelhas de interpretação da experiência religiosa. Este conjunto heterogêneo de elementos formou uma mística vernacular que atribuiu novos significados às entidades liminais próprias do universo religioso do Norte de Portugal. A linguagem da mística vernacular construiu a interioridade de uma experiência que, em sua singularidade, foi sempre fortemente socializada.
\end{abstract}

Palavras-chave: santidade popular; mística; medicina e psiquiatria; liminalidade; Alexandrina de Balasar.

\section{ABSTRACT}

On a first approach, the religious personality of Blessed Alexandrina Maria da Costa strikes us as strange and disconcerting. An exercise in historical and anthropological comprehension, this article reduces such strangeness. It is argued that this case reflects the history of a local community with a strong religious identity, in which devotional forms of Catholicism combined with initiatives on the part of the clergy aiming to promote spiritual subjectivities. At the same time, Medicine and Psychiatry provided new interpretation frameworks regarding religious experiences. From this ensemble of heterogeneous elements eventually emerged a vernacular form of mysticism, within which the traditional liminal entities acquired new meanings. The language of vernacular mysticism constructed the interiority of an experience that, albeit singular, was always strongly socialized.

Keywords: popular sainthood; mysticism; Medicine and Psychiatry; liminality; Alexandrina de Balasar.

\footnotetext{
*Agradeço a leitura e as valiosas sugestóes de Maria de Lurdes Rosa, assim como os comentários dos pareceristas da revista Topoi. Agradeço também as discussões de versões preparatórias deste artigo com meus colegas do Centro de Estudos de História Religiosa (Universidade Católica Portuguesa) e do Cermes3/Universidade Paris Descartes. Este artigo foi elaborado no âmbito de um projeto de pós-doutoramento financiado pela Fundação para a Ciência e Tecnologia (Portugal). Artigo recebido em 13 de março de 2012 e aceito em 23 de maio de 2012.
} 
Em 2004, o papa João Paulo II beatificou uma mulher com pouca instrução, natural de uma pequena aldeia do Norte de Portugal, que, sofrendo de uma doença incapacitante, viveu toda a sua vida adulta presa a uma cama. Filha da sociedade rural do Minho, Alexandrina Maria da Costa (1904-1955) — Alexandrina de Balasar para os devotos —, foi assim formalmente reconhecida como portadora de uma experiência mística digna de ser apontada como exemplo. Em suas várias versôes, a vida de Alexandrina é o relato de um sofrimento físico e moral incessante, repleto de visóes, possessóes demoníacas, mortificaçôes, êxtases e fenômenos sobrenaturais. Tomadas à letra, as expressôes da sua vida interior, de uma tonalidade melancólica comparável à de doentes psiquiátricos, são um desfiar de horrores:

Morri, morri para o mundo, morri para tudo. Deu o último suspiro aquele pequenino sopro de vida que já há muito vinha a agonizar, desaparecendo de toda a força que o arrastava pelo cemitério imenso. Até os próprios bichos desapareceram, aqueles que vinham sobre as minhas cinzas e sobre outras que não eram minhas, mas que estavam ao meu cuidado. Há dias que principiou a cair uma chuva de sangue, vinda do alto. Choveu sangue e ainda continua a chover. A princípio banhou as cinzas. Depois levou-as de tal forma até que desapareceram, já não existe nada. O sangue continua a vir do alto; cai sobre o que está limpo, já não tem mais que lavar. ${ }^{1}$

Noutro exemplo,

a minha vida é morte; continuo a viver a vida dos mortos. Que imensa sepultura, em que podridão estou sepultada; causa-me nojo, causa-me horror. Sinto-me a ser comida pelos bichos escondidos nesta podridão; sinto-os a mexer e remexer nesta imundície. E não tenho outra vida a não ser esta, nem outra luz a não serem as trevas do meu espírito. Triste cegueira que não me deixa ver senáo horrores nojentos, apodrecidos. ${ }^{2}$

Porém, simultaneamente, Alexandrina glorifica este sofrimento, entregue a Deus pela expiação dos pecados da humanidade e pela reparação do mal do mundo. Essa dádiva redentora do sofrimento faz destes "êxtases mortos", como lhes chama Alexandrina, uma fonte de vida. ${ }^{3}$ Se tivermos em conta que Alexandrina é contemporânea da psiquiatria moderna e da imagem fotográfica - elementos que integraram sua vida e persona religiosas —, esta experiência e sua linguagem espiritual são dificilmente compreensíveis dentro dos parâmetros habituais da contextualizaçáo histórica. Com efeito, a experiência de Alexandrina cristaliza elementos que remetem para várias temporalidades. Esta hipótese servirá de ponto de partida a este estudo.

\section{Heranças múltiplas, temporalidades cruzadas}

Num importante ensaio de antropologia histórica, Le sang et le ciel, Jean-Pierre Albert deu uma formulação sistemática ao conjunto de tópicos estruturantes da santidade feminina cristã. Analisando o tecido narrativo formado ao longo de séculos de hagiografias, Albert parte da hipótese de que a santidade feminina é particularmente problemática para o catolicismo. Essa hipótese resulta da conjugação

\footnotetext{
${ }^{1}$ COSTA, Alexandrina Maria da. Sentimentos da alma. 24 out. 1944. In: <alexandrinabalasar.free.fr/folhas_vejo_tantas_ coisas.htm>. Acesso em: 10 maio 2011.

${ }^{2}$ Ibidem, 13 jun. 1947 (dia da festa do Sagrado Coração de Jesus). In: <alexandrinabalasar.free.fr/alex_transverberacao. htm>. Acesso em: 10 maio 2011.

${ }^{3}$ Segundo os hagiógrafos, a 11 de fevereiro de 1955, Jesus disse a Alexandrina: "Repete o teu Creio; são êxtases de fé, de dor, de amor. São êxtases mortos, para darem vida”. PASQUALE, Humberto (S.D.B.). Beata Alexandrina. 9. ed. Maia: Ediçôes Salesianas, 1998. p. 228.
} 
De corpo e alma na margem: Catolicismo, SANtidade e medicina no Norte de Portugal (C. I900 - C. I950)

Tiago Pires Marques

de duas observaçóes: o muito menor número de canonizações femininas que masculinas, e certas elementos recorrentes nas figuras femininas de santidade. ${ }^{4}$ Relativamente a esse segundo aspecto, o autor observa que no corpus de hagiografias analisadas sobressai a referência à mística, motivo que acompanha certa desmesura na experiência da dor e do sofrimento, na forma de mortificaçôes e de atos repugnantes visando a degradaçáo física, de suplícios e de doenças que adquirem um valor penitencial. Segundo Albert, a experiência mística da dor e da degradação da carne, acentuando o carácter heroico da personalidade em causa, e por conseguinte a natureza viril da sua espiritualidade, revela que a santidade feminina é construída no interior de um modelo estruturalmente masculino. ${ }^{5}$

Este aspecto é, para o autor, revelador da posição da mulher neste universo simbólico: em virtude de uma impureza constitutiva, de que o sangue menstrual é a marca mais visível, a mulher não pode, mantendo as características da sua natureza feminina, projetar-se no campo do divino. ${ }^{6}$ Desta lógica decorre a negação da capacidade de mediar no acesso ao sagrado, patente na recusa do sacerdócio feminino. Porém, essa mediação torna-se possível num regime excepcional ou anômalo, o do casamento místico com Cristo, em que a mulher morre carnalmente oferecendo sua virgindade ao Redentor. Este regime de santificação inclui um processo de desincarnação, através do qual a mulher transcende, através de atos heroicos de mortificação e autodegradação, seu corpo feminino. O tópico dos "jorros de sangue" e a "bulimia eucarística", recorrentes nas hagiografias de santas, vêm, assim, simbolizar as núpcias da mulher, em processo de santificação, com Cristo. A sacralidade feminina no mundo cristão repousa, pois, segundo esse autor, na negação das funçôes biológicas naturais da mulher, em particular, as da reprodução. Ora, na tradição hagiográfica cristã, esse aspecto é sublinhado pela prática do jejum e pelo tópico da cessação das excreçôes "animais", substituídas por excreçôes de referência floral (os "odores de santidade"). A conjunção desses tópicos constitui o mito da "inédia", central na tradição hagiográfica das místicas do catolicismo. ${ }^{8}$

Num estudo anterior sobre a mesma fenomenologia, e em particular sobre as formas radicais de jejum praticadas por mulheres, a historiadora Caroline W. Bynum, ainda que reconhecendo o carácter estruturante de alguns destes elementos — como o dualismo entre corpo e alma, a associaçáo da santidade à renúncia dos prazeres do corpo, a dificuldade de acesso das mulheres à santidade —, distanciara-se deste tipo de interpretação. Em vez de associar o jejum a uma misoginia interiorizada e, portanto, a uma forma inconsciente de autopunição, Bynum pôs em evidência os significados religiosos positivos associados a certas formas de sofrimento, assim como o empowerment feminino, e exclusivamente feminino, que ele permite. ${ }^{9}$ Mas, por isso, tal empowerment torna-se perigoso, necessitando de interpretação e controlo clerical. No jejum jogava-se, por exemplo, a possibilidade de um controlo efetivo sobre um recurso vital - a comida - estreitamente ligado à função social atribuída às mulheres, a de a preparar e servir. Completado pela alimentação eucarística, o jejum era indissociável da experiência da "fusão mística" com Cristo. ${ }^{10}$

Representando estratégias de enfoque distintas, mas ambas igualmente sugestivas e bem fundamentadas, estes dois autores permitem hoje balizar este terreno de investigação. Se Albert é convincente na definição de constantes estruturais da santidade feminina cristá, sua dependência, pelo menos parcial, de pressupostos teóricos do estruturalismo e da psicanálise (como a correspondência simbólica

\footnotetext{
${ }^{4}$ ALBERT, Jean-Pierre. Le sang et le ciel. Les saintes mystiques dans le monde chrétien. s.l.: Aubier, 1997. p. 24.

${ }^{5}$ Ibidem, p. 410-413.

${ }^{6}$ Ibidem, p. 403-404.

${ }^{7}$ Ibidem, p. 416-419.

${ }^{8}$ Ibidem, p. 181-215.

${ }^{9}$ Agradeço a Maria Lurdes Rosa a precisão, neste ponto, relativamente a uma versão anterior.

${ }^{10}$ BYNUM, Caroline Walker. Holy feast and holy fast. The religious significance of food to Medieval women. Berkeley; Los Angeles; Londres: University of California Press, 1987. p. 218.
} 
De corpo e alma na margem: catolicismo, santidade e medicina no Norte de Portugal (c. I900 — C. I950)

Tiago Pires Marques

inconsciente entre o sangue das chagas de Cristo e o sangue menstrual) propóe às ciências humanas sérios problemas de validade científica, resultantes da impossibilidade de verificação empírica da hipótese psicanalítica. Por seu turno, o estudo de Bynum, focando a dimensão de agenciamento presente nas experiências descritas, defende bem a necessidade de ligar tais experiências religiosas a um contexto histórico táo vasto quanto possível e de inseri-las na rede de símbolos interconectados que lhes dá a densa espessura social que, segundo a historiadora, já não encontramos em experiências análogas nas sociedades modernas. ${ }^{11}$ Contudo, ainda que atenta às diferenças de gênero na construção das espiritualidades cristâs, a análise de Bynum dá pouca atenção às condicionantes institucionais e sociais das experiências religiosas em causa; por outro lado, não permite compreender a longa duração da tópica hagiográfica. Mas as duas perspectivas, de certa forma complementares, podem servir de base a uma nova tentativa de síntese histórico-antropológica da problemática da santidade. O caso de Alexandrina presta-se bem a este exercício, já que, pela riqueza de dados que nos fornece, permite examinar o problema da relação entre função/estrutura social e os significados/agenciamentos individuais na experiência religiosa.

Alexandrina pertence a um mundo que, em muitos aspetos, é distante do universo da santidade medieval. No entanto, sua experiência religiosa inclui elementos da tópica hagiográfica e ganha em ser analisada à luz dessa problemática. Por outro lado, Alexandrina de Balasar não foi, no seu tempo, um caso isolado. ${ }^{12}$ Nos textos que lhe são atribuídos ecoam, por exemplo, as declaraçôes do sofrimento, mais enunciado do que observado, de Maria de Loyola, fundadora da Congregação das Religiosas Adoradoras do Precioso Sangue, no início do século XX. Ora, como defendeu Albert, essas declaraçôes refletem o martírio de Santa Lydwine de Schiedam, no século XV, provocado por uma série interminável de doenças; martírio, enfim, que viria atualizar os inefáveis suplícios de Santa Cristina de Tyr, mártir cristã do final do século III d.C. ${ }^{13}$

Com efeito, na sua linguagem, a experiência e espiritualidade de Alexandrina são muito próximas das de mulheres místicas de outros tempos históricos. Veja-se, por exemplo, a história "santamente sórdida” de Louise du Tronchait (1639-1694) (autodesignada Louise du Néant), expressão de Henri Brémond na obra clássica Histoire littéraire du sentiment religieux en France. ${ }^{14}$ Tal como em Alexandrina, a doença é a matéria-prima de um processo de identificação crística, numa vida "toda crucificada"; e a mortificação do corpo, a humilhação e a aniquilação de si são meios de santificação. Louca e fazendo-se passar por louca, seus gritos horrorizavam as irmãs da comunidade de Charonne, onde procurou acolhimento religioso. Como Alexandrina, Louise foi tida por possessa e por bruxa. ${ }^{15}$ Enfim, também ela exterior à instituição religiosa, Louise du Néant ofereceu-se em "holocausto vivo" pela expiação dos pecados do mundo. ${ }^{16}$ Guiada por vários diretores espirituais, que garantiram a ligação com a tradição mística cristâ, Louise du Néant é um bom exemplo da "via de abjeção" valorizada pelos jesuítas na França do século XVII. Porém, o caminho dessa mística conduziu, não a um reconhecimento de santidade, mas ao internamento, por alienação mental, no asilo da Salpêtrière. Para as autoridades religiosas desta época, determinadas a combater os excessos e os fenômenos extraordinários da vida

\footnotetext{
${ }^{11}$ Ibidem, p. 7 e 298.

${ }^{12}$ Maria de Lurdes Rosa cita este e outros casos, em Portugal, onde a tópica da santidade medieval ecoou em manifestaçôes religiosas durante os séculos XIX e XX. ROSA, Maria de Lurdes. Hagiografia e santidade. In: AZEVEDO, Carlos Moreira (Org.). Dicionário de história religiosa de Portugal. Rio de Mouro: Círculo de Leitores, 2000. p. 326-361, 331 e 335; ROSA, Maria de Lurdes. Santos e demônios no Portugal medieval. Porto: Fio da Palavra, 2010. p. 76-80.

${ }^{13}$ ALBERT, Jean-Pierre. Le sang et le ciel, op. cit. p. 16-19.

${ }^{14}$ BREMOND, Henri. Histoire littéraire du sentiment religieux en France. vol. 5 - La conquête mystique. Paris: Librairie Bloud et Gay, 1933. p. 345.

${ }^{15}$ Ibidem, p. 352-353.

${ }^{16}$ GIMARET, Antoinette. Louise du Néant, une sainteté problématique. L’Atelier du Centre de Recherches Historiques, v. 4, p. 2, 2009. Disponível em: <http://acrh.revues.org/index1354.html>. Acesso em: 11 maio 2012.
} 
De corpo e alma na margem: Catolicismo, SANtidade e medicina no Norte de Portugal (C. I900 - C. I950)

Tiago Pires Marques

espiritual, essa mística surge já como suspeita, desviante, figura mais patológica do que religiosa. ${ }^{17}$ Ora, no universo católico, esta fenomenologia e tópica religiosas seriam, durante o século XVIII, objeto de um escrutínio teológico sustentado em guiôes normativos rigorosos na codificação da experiência religiosa. E no tempo de Alexandrina eram objeto de uma crítica de inspiração científica e racionalista, surgindo para muitos clérigos como anacrônicas ou mesmo reveladoras de personalidades patológicas. ${ }^{18}$

Importa, pois, inquirir sobre as circunstâncias que tornaram possível a reatualizaçấo histórica desta tópica numa pequena aldeia do Norte de Portugal durante a primeira metade do século XX. Sabemos que Alexandrina foi, antes de mais, uma "santa viva", no sentido das formas de religiosidade geralmente apelidadas de populares. Os elementos sobrenaturais da experiência de Alexandrina evidenciam esse substrato popular. Náo será assim possível resolver comodamente a questão pela leitura da experiência de Alexandrina à luz de um referencial de religiosidade popular, atribuindo-lhe simultaneamente características patológicas? Mas como explicar, neste caso, o investimento espiritual e afetivo dos múltiplos intervenientes, vários deles pertencentes à hierarquia clerical, na vida de Alexandrina? Para abordarmos estas questôes, é necessário conhecer melhor sua história.

\section{As narrativas hagiográficas}

\section{a) Metodologia}

São atribuídos a Alexandrina três conjuntos de textos: uma Autobiografia, datada de 1943 ou 1944, sucedendo ao seu internamento para observação num hospital da região do Porto; um corpo de reflexôes espirituais e biográficas recolhidas entre 1944 e sua morte em 1955, a que se deu o título de Sentimentos da alma, e duas recolhas do mesmo tipo publicadas pelo padre salesiano Humberto Pasquale (segundo diretor espiritual de Alexandrina); ${ }^{19}$ e ainda várias cartas aos diretores espirituais, médicos e personalidades várias. Porém, estes textos não foram escritos pela mão de Alexandrina, tendo sido ditados a várias pessoas próximas, nomeadamente a irmá Deolinda, a professora da escola de Balasar e o médico assistente, Manuel Augusto Dias de Azevedo. Por outro lado, os textos atribuídos a Alexandrina inserem-se invariavelmente num conjunto textual onde se verificam múltiplas interferências de terceiros. Não existindo, de momento, versôes estabilizadas dos textos místicos de Alexandrina, sua produção espiritual é-nos acessível através de um palimpsesto vasto e multiforme cuja autoria é, na realidade, mais coletiva que individual.

Em 1956 surgiu a primeira biografia, assinada pelo padre Mariano Pinho, com o título Uma vítima da Eucaristia. Alexandrina Maria da Costa, a doentinha de Balasar; a esta seguir-se-ia uma biografia aumentada, No calvário de Balasar, com primeira edição em 1963. Ambas foram inicialmente publicadas no Brasil, sendo atualmente este país um dos focos da devoção a Alexandrina. No fim da década de 1960, teve início o processo de beatificação, promovido pelo segundo diretor espiritual, o sacerdote italiano Humberto Pasquale. ${ }^{20}$ A sua apresentação foi publicada com o título Eis a Alexandrina. Postulação da causa (1967). No contexto do movimento pela beatificação, foram traduzidas para o italiano muitas das alocuçôes de Alexandrina. A tradução foi realizada por um casal de professores italianos, Chiaffre-

\footnotetext{
${ }^{17}$ Ibidem, p. 8 e 23-24.

${ }^{18}$ BYNUM, Caroline Walker. Holy feast and holy fast, op. cit. p 74; MARQUES, Tiago Pires. Mystique, politique et maladie mentale. Historicités croisées (France, c. 1830 - c. 1900). Revue d'Histoire des Sciences Humaines, n. 23, p. 37-74, déc. 2010. p. 48.

${ }_{19}$ Artigos biográficos da Serva de Deus Alexandrina Maria da Costa. Porto: Empresa de Publicidade do Norte, 1966; e $A$ paixão de Jesus em Alexandrina Maria da Costa. Porto: Edições Salesianas, 1979.

${ }^{20}$ Sobre o processo de beatificação, Kenneth Woodward fornece dados de grande interesse: WOODWARD, Kenneth L. Comment l'église fait les saints. Paris: Grasset, 1992. p. 181-189.
} 
De corpo e alma na margem: Catolicismo, SANtidade e medicina no Norte de Portugal (C. I900 - C. I950)

Tiago Pires Marques

do e Eugenia Signorille, considerados autoridades na espiritualidade da beata de Balasar pelos devotos. De entre as várias obras apologéticas consagradas a Alexandrina, devem referir-se a biografia do padre Humberto Pasquale, Alexandrina (já com nove ediçóes), ${ }^{21}$ e seu opúsculo intitulado Fátima e Balasar. Duas terras irmãs (1979). Em 1994, foi publicada uma biografia da autoria do padre Gabriele Amorth, Por detrás de um sorriso (original italiano, de 1992) e, mais recentemente, de Leo Madigan, Alexandrina da Costa. The mystical martyr of Fatima (2005). ${ }^{22}$

Atualmente, a devoção e a espiritualidade de Alexandrina são promovidas, em grande medida, pela internet. Destaca-se o site autointitulado oficial, de caráter devocional, dinamizado por Afonso Rocha, emigrante em França e tradutor para o francês de uma biografia de Alexandrina. ${ }^{23}$ Composto por centenas de páginas, esse sítio apresenta, em várias línguas (incluindo o inglês, o italiano, o francês, o japonês e o mandarim), um grande acervo de informaçóes sobre Alexandrina, assim como uma surpreendente coleção de material fotográfico, vídeo e iconográfico. Refiram-se ainda os sítios devocionais de José Ferreira, alguns muito especializados (como o blog dedicado apenas ao jejum da Beata; ver bibliografia).

A base documental deste estudo é, pois, constituída pelos textos de Alexandrina, as biografias dos dois diretores espirituais ${ }^{24}$ e documentos citados ou reproduzidos nos referidos sítios devocionais. Ora, essas fontes têm invariavelmente uma natureza hagiográfica, o que remete para uma lógica de construção bem codificada. Neste caso, a essa forma de produção discursiva se acresce um conjunto de mediaçóes de leigos, nos quais a codificação hagiográfica tradicional se combina com outros tipos de lógica. Além disso, a apresentação de um santo na internet para fins devocionais coloca problemas específicos. Na senda de autores como Manuel Castells e Pierre Lévy, o antropólogo Paolo Apolito, por exemplo, observou a relação entre movimentos religiosos contemporâneos e o espaço cibernético. Em The internet and the Madonna, Apolito refere-se a uma "colonização tecnológica" do imaginário católico, com consequências importantes nas práticas e representaçóes religiosas. Segundo Apolito, a fotografia, o vídeo e a internet tendem a tornar obsoleta "a tensão entre carisma e instituiçáo": para contatar com o divino, o devoto pode prescindir da presença da personalidade carismática ou visionária e da instituição eclesiástica. ${ }^{25}$ Os movimentos devocionais, com origem local, e portanto fortemente enraizados em contextos experienciais coletivos, tendem, por essa via, a uma desterritoralização. Verifica-se uma "deslocalização do sagrado", numa tensão entre a universalizaçáo de uma mensagem local e o que William Christian chamou, ainda que noutro contexto, de "clonagem da paisagem do sagrado". ${ }^{26}$

No âmbito deste artigo, não é possível aprofundar estas questóes, essenciais se quisermos empreender um estudo etnográfico do culto contemporâneo de Alexandrina. Porém, importa ter presente que, ao utilizar fontes obtidas na internet, nos encontramos, pelo menos formalmente, na posição do internauta devoto descrito por Apolito,

(...) obrigado a descontextualizar e recontextualizar tudo o que surge ao seu alcance, retirando todos os elementos do contexto no qual eles foram produzidos ou no qual foram inseridos, conectando-os com outros

\footnotetext{
${ }^{21}$ A partir de 1998, ainda antes da beatificação, o título foi modificado para Beata Alexandrina. A primeira edição é de 1960.

${ }^{22}$ Esta lista, não exaustiva, pode ser completada com as referências indicadas por: ROSA, Maria de Lurdes. Hagiografia e santidade, op. cit., p. 349.

${ }^{23}$ Disponível em: <http://alexandrinabalasar.free.fr/>.

${ }^{24}$ A biografia do padre Mariano Pinho está também disponível em linha: <http://alexandrinabalasar.free.fr/no_calvario_ indice.htm>. Acessoo em: 15 jan. 2010.

${ }_{25}$ APOLITO, Paolo. The internet and the Madonna. Religious visionary experience on the web. Chicago: University of Chicago Press, 2005. p. 101.

${ }^{26}$ CHRISTIAN JR., William. Person and God in a Spanish valley. Nova York: Seminar Press, 1972. p. 48, 181-182. Cit. por APOLITO, Paolo. The internet and the Madonna, op. cit. p. 152-153.
} 
De corpo e alma na margem: Catolicismo, SANtidade e medicina no Norte de Portugal (C. I900 - C. I950)

Tiago Pires Marques

elementos, com outros contextos relativamente provisórios, e eventualmente com todos os outros objetos. Mesmo quando o internauta mantém as contextualizaçóes oferecidas pelo site, ele não faz outra coisa senão usar o seu próprio poder de recontextualização de acordo com as possibilidades ao seu dispor, que só por coincidência correspondem com a configuração do site. ${ }^{27}$

Neste caso, os autores dos sites facilitam a necessária operação de descontextualização/recontextualização, pelo fato de, regra geral, identificarem os documentos fixados previamente - como as biografias, por exemplo — , permitindo, assim, separá-los dos comentários posteriormente adicionados. Comparando com as fontes impressas, é interessante observar, para além da recontextualização da experiência de Alexandrina, uma reorganização do espaço documental: por exemplo, algumas peças documentais, que assumiam pouco relevo no arquivo material, nomeadamente no conjunto das fontes impressas (essencialmente clericais), adquirem agora maior visibilidade. É o caso, por exemplo, dos relatórios clínicos. Noutros casos, comparando o material colocado em linha com os textos impressos, observamos pequenas diferenças, indiciadoras de um trabalho de triagem por parte dos intervenientes clericais. Nas versóes impressas - por exemplo, a biografia assinada pelo padre Humberto Pasquale os textos de Alexandrina aparecem na forma de excertos e a sua linguagem foi claramente objeto de alguma depuração. Por outro lado, os sites referidos contêm imagens fotográficas dos documentos, possibilitando, nalguns casos, um acesso direto ao seu conteúdo. Assim, optei, regra geral, por citar os textos de Alexandrina na versão encontrada nos sites indicados, o que permitirá ao leitor aceder facilmente às fontes. Porém, mais do que acrescentar informação, neste caso, a internet vem, sobretudo, reordenar um conjunto arquivístico previamente constituído.

A confrontação dos dois tipos de arquivos — cibernético e material — põe em evidência a multiplicidade de intervençóes operatórias na construção desta personalidade religiosa. Veremos, com efeito, que a vida e a experiência religiosa de Alexandrina se constituem numa teia complexa de agenciamentos e são objeto de sucessivas mediaçóes. O estudo deste caso é, pois, em boa medida, uma observação de tais agenciamentos e mediaçóes, na diversidade das suas lógicas, códigos e objetivos.

Foi através das hagiografias, impressas e publicadas nos sites referidos, e de peças clínicas colocadas em linha que tomei conhecimento dos relatórios médicos. Contrariamente ao que aconteceu com os textos religiosos, não pude comparar essas peças clínicas com seus originais impressos, já que não tive acesso ao arquivo hospitalar. Porém, mais do que a referência a uma "realidade clínica" que contribuiria para a elucidação de um "caso", é a inclusão dessas peças médicas no material hagiográfico que me parece aqui significativa. Trata-se, com efeito, de observar como a medicina e a psiquiatria se inscreveram no dispositivo hagiográfico. Por outro lado, estes documentos médicos, ainda que mediados pela narrativa hagiográfica, dão-nos informação relevante sobre o posicionamento dos médicos e psiquiatras em relação à experiência da mística.

Enfim, tendo em conta a natureza muito mediada das fontes disponíveis, pareceu-me necessário complementar esse corpo de fontes com testemunhos de pessoas que acompanharam o caso em Balasar. Para esse efeito, desloquei-me à povoação minhota em março de 2010, março de 2011 e outubro de 2011, onde realizei várias entrevistas e observaçóes. Neste trabalho, mobilizando uma metodologia de história oral, tornou-se claro que tais testemunhos captam as ressonâncias contemporâneas da vida

\footnotetext{
27 “(...) obliged to decontextualize and recontextualize everything that comes within reach, extracting everything from the context in which it was produced or into which it was inserted, connecting it to other things, other relatively provisional contexts, and to virtually all other things. Even when the surfer preserves the contextualizations offered by the site, she does nothing other than use her own power of recontextualizing according to the possibilities at her disposal, which only coincidently correspond to the configuration of the site itself." Ibidem, p. 224. (minha tradução).
} 
De corpo e alma na margem: Catolicismo, SANtidade e medicina no Norte de Portugal (C. I900 - C. I950)

Tiago Pires Marques

religiosa de Alexandrina e refletem as formas atuais do seu culto. Por conseguinte, remetem para uma problemática que, tal como o proselitismo cibernético, se situa fora do âmbito deste artigo. Ainda assim, tomei em consideração alguns dos elementos recolhidos, que se revelaram úteis para validar elementos essenciais decorrentes das fontes publicadas - por exemplo, quando esses elementos têm aí apenas uma presença pontual, e não tópica - ou para fundamentar certas inferências às quais faltava uma base sólida. Esses testemunhos vieram, assim, confirmar os seguintes elementos, cruciais, recolhidos na documentação publicada: a existência de interpretaçóes locais representando Alexandrina como bruxa; a sua situação inicial de relativa marginalidade e de grande carência econômica, e a sua progressiva integração numa rede de solidariedade local; a presença e importância dos diretores espirituais e outros sacerdotes, assim como a do médico Manuel Dias de Azevedo; e, enfim, a ligação de Alexandrina, familiares e pessoas próximas a movimentos religiosos devocionais. Do testemunho de uma pessoa próxima de Alexandrina, conhecedora das várias obras que sobre ela se escreveram e que aqui utilizo como fontes, ficou também a nota de grande adesão às narrativas hagiográficas publicadas. Para a pessoa em causa, que acompanhou de perto a vida de Alexandrina durante longos anos, estas obras contam a "verdade". Este aspecto indicia que, pelo menos nalguns casos, a memória de Alexandrina é hoje balizada, senão mesmo mediada, por essas narrativas.

\section{b) Alexandrina Maria da Costa: uma vida de doença e paixão}

Vejamos então brevemente as principais etapas do seu percurso de santificação, tal como nos é dado pelas narrativas biográficas e hagiográficas, em particular na sua Autobiografia. Nascida numa "quarta-feira de trevas" e batizada num "Sábado de Aleluia", Alexandrina tem da sua infância uma imagem globalmente feliz, ainda que se detectem já prenúncios da sua vocação religiosa e sofredora. É muito devota de Nossa Senhora, a quem chama a "Mãezinha", ama apaixonadamente as "florzinhas" do campo, tema recorrente em sua literatura espiritual, e desde muito nova ajuda os vizinhos a vestir os defuntos. Na Póvoa de Varzim, recebe uma instrução sumária e é contratada para trabalhar em casa de um homem da aldeia, um "vizinho", que descreve como um "carrasco". Volta à casa materna para fugir dos maus tratos que lhe inflige o vizinho carrasco; porém, este a procura em casa e tenta violá-la. Para escapar, Alexandrina salta da janela do quarto e cai em falso. Esta queda - tem Alexandrina entáo quatorze anos - seria a origem de todas as suas afliçôes futuras. Perdendo progressivamente a capacidade de andar, Alexandrina procura os médicos e é-lhe diagnosticada uma mielite lombar. Experimenta vários tratamentos médicos, mas sem sucesso. Em 1924, aos 19 anos, fica definitivamente acamada.

Tal como em muitos casos da mística feminina cristá, a personalidade religiosa de Alexandrina começa a ganhar forma a partir da constatação da doença incurável: este momento marca, na narrativa autobiográfica, o início da "via mística". Paraplégica, sofrendo de grandes dores físicas e morais, Alexandrina consagra-se a uma existência religiosa radical, durante a qual tem inúmeras visóes, é objeto de tentaçóes, possessóes demoníacas e de êxtases.

No início dos anos 1930, Alexandrina chama a atenção do padre jesuíta Mariano Pinho, que se torna seu diretor espiritual. Segundo os relatos, foi o jesuíta que lhe permitiu compreender o sentido religioso do seu sofrimento e da sua via espiritual. Porém, durante esta década, Alexandrina atravessará várias crises espirituais, com prenúncios de morte, o sentimento de estar moribunda, e, como atrás se viu, de ter morrido. A sua aflição é aliviada quando o diretor espiritual a informa de que se trata da "morte mística", que serve como purificação interior antes de uma união mais profunda com Cristo, fato a que a nossa entrevistada próxima de Alexandrina atribuiu grande importância. ${ }^{28}$

\footnotetext{
${ }^{28}$ Disponível em: <http://alexandrinabalasar.free.fr/autobiografia_2.htm>. Acesso em: 15 jan. 2010. Caderno de notas, 4-3-2010 e 13-10-2011.
} 
De corpo e alma na margem: catolicismo, santidade e medicina no Norte de Portugal (c. I 900 - C. I950)

Tiago Pires Marques

Entre 1938 e 1942, Alexandrina revive a paixão de Cristo sob o olhar perplexo ou curioso daqueles que, em número crescente, se juntam no seu quarto. Ao calvário e à crucifixão segue-se o êxtase. Cessando as paixôes em 1942, continuarão a se verificar êxtases todas as sextas-feiras. É em torno desses fenômenos que se acendem as primeiras polêmicas. A controvérsia é médica e teológica, opondo médicos e teólogos entre si, mais do que homens de ciência a homens de religião, e tem por objeto a experiência de Alexandrina. Qual a sua natureza? Simulação, manifestação patológica ou experiência religiosa? Em 1943, depois de um exame prolongado num hospital do Porto, sentindo a proximidade da morte, Alexandrina dita a sua Autobiografia à professora da escola local e à irmá, testemunho da sua vitória espiritual sobre os descrentes e a medicina.

Alexandrina viveria ainda onze anos, mas a sua condição física não melhorou. A via mística, essa, foi-se sempre radicalizando. Em 1946 Alexandrina pediu para ser colocada sobre tábuas duras, assim permanecendo, até ao fim da vida, sem comer, beber ou dormir. ${ }^{29} \mathrm{Em} 1953$, o médico assistente, Manuel Dias de Azevedo, publicava num periódico local uma notícia do caso extraordinário desta mulher,

em abstinência absoluta de alimentos há 12 anos (...) de vida intelectual e afetiva intensas, de faculdades e sentidos normais, sem os menores sintomas de histeria ou outra neuropsicose, passando dias e noites sem dormir ou dormindo muito pouco, conservando invariavelmente, ou com pequena variação, o mesmo peso, de pulsaçōes e tensōes arteriais normais, sustentando conversas inteligentes sem o menor deslize intelectual. ${ }^{30}$

Alexandrina morreu com fama de santidade a 13 de outubro de 1954. Ao seu enterro vieram milhares de pessoas e a sua memória permanece hoje viva em Balasar.

Os relatos hagiográficos póem a ênfase nos aspectos religiosos, sobretudo nos elementos miraculosos e sobrenaturais. No entanto, uma análise fina desses relatos permite ver que a vida de Alexandrina se constrói no cruzamento das intervençóes de múltiplos atores. Os sacerdotes e os médicos surgem como personagens destacadas, mas o tecido social em que se inscreve a experiência de Alexandrina é dado pela comunidade local, em particular pelo núcleo familiar e pelos "vizinhos". Assistida pela mãe, por uma irmá, pela professora da escola, pelos vários párocos locais e por outros familiares e amigos, a doença de Alexandrina e suas experiências religiosas foram intensamente socializadas. Por outro lado, a sua personalidade espiritual construiu-se, em boa parte, pela mobilização da clínica médica e da imprensa. Como veremos, nos relatos da experiência mística os temas médicos entretecem-se com elementos sobrenaturais e espirituais. Em suma, longe de se poder ler como simples ativação patológica de uma religiosidade popular, a experiência religiosa de Alexandrina parece literalmente ganhar corpo na confluência de um conjunto de elementos heterogêneos.

Para efeitos de análise, estas mediaçóes serão aqui situadas em três níveis diversos, segundo o seu grau de proximidade com a vida quotidiana de Alexandrina: a comunidade local, a mediação clerical e a mediação médica. Essa tripartição enferma obviamente de certa artificialidade, já que tais mediaçôes existiram de forma imbricada. Por outro lado, náo é analisado o papel da imprensa, que teve algum impacto na construção desta personalidade religiosa, nem as relaçôes conhecidas entre Alexandrina e algumas instâncias do poder político. Sem pretender fornecer uma análise exaustiva do caso, o estudo que se segue deve ser entendido como uma tentativa de compreensão, consciente dos limites decorrentes da natureza dos documentos de que dispomos e da prudência epistemológica própria das ciências humanas.

\footnotetext{
${ }^{29}$ PASQUALE, Humberto, Beata Alexandrina, op. cit. p. 24.

${ }^{30}$ AZEVEDO, Manuel Dias de. O caso de Balazar. Palavras amigas e de verdade. Diário do Norte, 30 jun. 1953. Disponível em: <alexandrinabalasar.free.fr/a_beata_alexandrina_na_imprensa.htm>. Acesso em: 23 fev. 2011.
} 


\section{A integração social pela margem}

O Minho rural do tempo de Alexandrina tinha por unidade de base a pequena propriedade agrícola, estruturando-se mediante relaçóes familiares, de solidariedade comunitária agregando vizinhos, e através de formas religiosas de sociabilidade. Entre estas, salientem-se as várias dinâmicas da vida paroquial e o envolvimento em ordens terceiras, em movimentos devocionais e espirituais e a participação em peregrinaçóes. Porém, no início do século XX, após um século de rápidas transformaçóes políticas e socioeconômicas, uma forte emigração para o Brasil indiciava uma situação de crise na região. Alexandrina é, em boa medida, produto desse contexto: filha ilegítima de um pai emigrado no Brasil, e portanto carecendo de proteçâo paterna, ficou aos cuidados da mãe, do pároco local e dos vizinhos. A situação de Alexandrina e de sua família eram, segundo elementos recolhidos junto da populaçáo local, de extrema pobreza. Incapaz de se sustentar, de cooperar nas tarefas do quotidiano e de cumprir os deveres religiosos, a posiçáo social de Alexandrina era frágil. A doença deixava-a à mercê da comunidade.

Outro aspecto merece atenção. Elemento recorrente na produçáo espiritual de Alexandrina, o tópico da morte tem um referente histórico e um enquadramento antropológico precisos. Em 1835 e 1845, foram promulgadas as chamadas Leis de Saúde Pública, proibindo os enterros nas igrejas e decretando a obrigatoriedade de construção de cemitérios fora das localidades. Essas leis vieram consagrar a política higienista e uma nova atitude perante a morte entre as classes dirigentes. No Minho, a reação popular e clerical contra a sua aplicação foi particularmente violenta, constituindo um dos fatores na origem dos motins da Maria da Fonte, em 1846, com forte expressão feminina. Note-se que a sublevação popular foi desencadeada pela repressão das autoridades policiais de uma tentativa de enterramento numa igreja (para a população local, fora da igreja o morto ficava "desprotegido"). O antropólogo João Pina Cabral atribui particular significado a este aspecto, observando que, em resultado da resistência popular, a construção de cemitérios na regiâo teve início apenas nos finais do século XIX; porém, segundo ele próprio constatou, ainda nos anos 1970 existiam localidades sem cemitérios. ${ }^{31}$

Estes dois elementos são fundamentais para compreender a situação de Alexandrina e a sua história espiritual. A fragilidade da sua posição social manifesta-se num certo estado de passividade, de crescente incapacidade de agir, de sentimento de sujeição a um destino. A progressiva redução à cama exprime bem essa condiçáo. Ao mesmo tempo, a crise moral provocada pelas mutaçóes históricas, em particular no que respeita à relação com os mortos, criou novas necessidades de reparação e mediação simbólica. É nessa brecha entre uma situação sentida como fatalidade e as necessidades simbólicas da comunidade que Alexandrina viria a encontrar seu espaço. Os estudos etnográficos de João Pina Cabral, Giordana Charuty e Miguel de Montenegro sobre o Minho iluminam estes elementos.

Analisando os cultos da morte dos minhotos como formas análogas aos mitos, ${ }^{32}$ Pina Cabral mostrou que a morte é, nesta região, um processo social densamente codificado, envolvendo não apenas a morte física mas também o enterro e o luto. Tal processo constitui-se de uma série de práticas, ritos e crenças, através dos quais se conduz o morto ao outro mundo e se protege a comunidade das más influências a que fica exposta durante este trânsito. A este processo corresponde, pois, um período de liminalidade, caracterizado pelo sentimento de vulnerabilidade às "forças da morte", e no qual os membros da comunidade se recordam que também eles estão destinados a morrer. Neste sentido, a morte, enquanto acontecimento simbolicamente investido, fornece a ocasião para uma "experiência da comunidade". ${ }^{33}$

Desta experiência, Pina Cabral infere um primeiro elemento característico do sistema de crenças da comunidade rural minhota, partilhado com outras culturas cristãs. Trata-se do tema da descendência

\footnotetext{
${ }^{31}$ CABRAL, João de Pina. Sons of Adam, daughters of Eve. Oxford: Clarendon Press, 1986. p. 215.

${ }^{32}$ Ibidem, p. 235.

${ }^{33}$ Ibidem, p. 218-224.
} 
de Adão e Eva: em resultado do pecado original, todos os homens e mulheres foram condenados a viver num mundo corrompido onde, independentemente da posição social, a morte física é um fim inelutável. O antropólogo analisa, de seguida, três formas cultuais em que a mundividência dos camponeses do Minho se manifesta com particular intensidade, que reúne sob a designação de cultos de morte: o culto das almas do Purgatório, dos corpos incorruptos e das jejuadoras. Segundo Pina Cabral, esses três cultos reportam-se a posiçóes de liminalidade (i.e., entre dois mundos, neste caso o dos vivos e o dos mortos). ${ }^{34}$ As almas do Purgatório são, por definição, seres em trânsito: pela sua condição, estão mais próximas das almas dos vivos do que aquelas que já se encontram no Paraíso. Assim, rezar pelas almas do Purgatório levará a que estas, uma vez no Paraíso, intercedam junto de Deus pela salvação de quem por elas rezou. Por seu turno, os corpos incorruptos encontram-se igualmente numa posição liminal: dado que estar vivo significa ter um corpo, metaforicamente os corpos incorruptos estáo simultaneamente mortos e vivos. Por outro lado, no caso de corpos femininos, o corpo incorrupto sugere uma relação causal entre virgindade e a não corrupção física. Essa associação é, para o antropólogo, particularmente evidente no culto mariano, pela relação entre a pureza da Virgem e sua assunção ao Céu. ${ }^{35}$

No terceiro tipo de cultos de morte — o culto das jejuadoras —, Pina Cabral refere muito brevemente o caso de Alexandrina de Balasar, que observou, não sob o prisma da experiência subjetiva e dos significados espirituais nela investidos, mas precisamente enquanto objeto de culto. Detectando características semelhantes aos cultos de corpos incorruptos, Pina Cabral nota que nos outros dois casos de cultos de jejuadoras de que teve conhecimento se tratava de mulheres com reputação de "pureza" (i.e. virgindade). No caso de Alexandrina, a doença, causada por um ato visando proteger a pureza sexual, reforça e exprime, segundo o autor, o valor de pureza inerente ao carisma religioso. ${ }^{36}$

Numa recensão do livro de Pina Cabral, Caroline W. Bynum salienta as virtualidades interpretativas dessa abordagem antropológica (em contraponto às perspectivas psicologizantes), pela sua capacidade de inserir a "anorexia sagrada" no espaço simbólico do qual retira a sua significação religiosa. Para Bynum, é o jejum feminino, associado à comunhão periódica, que atualiza a natureza liminal do corpo da jejuadora: pela rejeiçáo da comida terrena, ou profana, a jejuadora situa-se fora do campo das necessidades físicas e da fertilidade (impura) e torna-se mediadora do alimento divino (a eucaristia). O corpo da jejuadora eucarística torna-se veículo e símbolo de uma transposição de limites (boundary crossing). ${ }^{37}$

Analisando também os cultos de morte do Alto Minho, Giordana Charuty pôs igualmente em evidência a função terapêutica de que, em certos casos, se reveste o objeto de culto. Permitindo ritualizar, e assim socializar o mal de que se sofre, os cultos de morte fornecem uma ritualidade que serve igualmente de enquadramento terapêutico. Cultos de morte e rituais terapêuticos estáo, pois, interligados, tanto mais que nesta região, segundo Charuty, as formas populares do tratamento, entretecendo-se de forma fragmentária no conjunto de gestos e práticas do quotidiano, não formam um sistema simbólico autônomo. ${ }^{38}$ Os estudos mais recentes de Miguel de Montenegro sobre as práticas terapêuticas tradicionais no Norte de Portugal vêm acrescentar um elemento importante a este quadro, ao mostrarem o vigor do sistema de bruxaria. Com os seus mediadores qualificados — dos quais se diz serem "corpo aberto" a bruxaria existe nas margens do sistema simbólico hegemônico, de referência católica, aí funcionando como dispositivo terapêutico. ${ }^{39}$

\footnotetext{
${ }^{34} \mathrm{Na}$ antropologia religiosa, foi um conceito desenvolvido por A. Van Gennep e Victor Turner.

${ }^{35}$ CABRAL, João de Pina, Sons of Adam, daughters of Eve, op. cit. p. 226-232.

${ }^{36}$ Ibidem, p. 233.

${ }^{37}$ BYNUM, Caroline Walker. Holy feast and holy fast, op. cit. p. 241.

${ }^{38}$ CHARUTY, Giordana. Folie, mariage et mort. Pratiques chrétiennes de la folie en Europe occidentale. Paris: Seuil, 1998. p. 13.

${ }^{39}$ MONTENEGRO, Miguel de. Les bruxos: des thérapeutes traditionnelles et leur clientèle au Portugal. Paris: L'Harmattan, 2005. p 81-85.
} 
De corpo e alma na margem: catolicismo, santidade e medicina no Norte de Portugal (c. I900 — C. I950)

Tiago Pires Marques

Ora, algumas passagens das hagiografias, assim como vários testemunhos de conterrâneos seus, recolhidos nas visitas a Balasar, revelam que Alexandrina foi, em vida como em morte, objeto de um culto mágico-terapêutico, não só por ser jejuadora, mas também por ser considerada um "corpo aberto": "Diziam que eu talhava o ar, fazendo de mim bruxa, que era corpo aberto; chegando várias pessoas a aproximar-se de mim para fazerem várias perguntas, como se eu adivinhasse", diz Alexandrina na Autobiografia. ${ }^{40}$

Como refere Montenegro, o "corpo aberto", característico do complexo cultural da bruxaria, designa um estado em que a pessoa se encontra particularmente vulnerável aos espíritos dos "maus mortos" e aos maus olhados. Se possuída, a vítima pode manifestar capacidades divinatórias, podendo ela própria tornar-se, como possível via de resolução da crise, bruxa ou bruxo. Neste caso, a possessão, antes selvagem, passa a ser controlada por um guia espiritual pessoal, frequentemente um santo, e a pessoa torna-se um agente terapêutico, sobretudo de doenças espirituais. ${ }^{41}$ Considerada "corpo aberto", Alexandrina pertencia, pois, a um meio marcado pelo sistema da bruxaria. Neste ponto, os meus informantes em Balasar, contemporâneos de Alexandrina, relatam episódios significativos de pessoas que lhe levavam roupas de terceiros para que, através delas, Alexandrina efetuasse, por artes mágicas, uma "cura" sobre os seus proprietários. Alexandrina combateu estes comportamentos, que considerava humilhantes, e as interpretaçóes de que era bruxa, classificando-as de boatos e mobilizando símbolos pertencentes ao universo católico. ${ }^{42}$ No entanto, a sua posição de mediadora entre o mundo dos vivos e dos mortos, inscrevendo-se formalmente na sacralidade católica veiculada pelos sacerdotes do seu tempo, integrou plenamente a funçáo e alguns significados do sistema do "corpo aberto". O seu estatuto de santa viva cristianizou, sem as abolir, as qualidades mediúnicas e mágico-terapêuticas desse sistema.

Esta pluralidade de sentidos associados a Alexandrina, figura piedosa convertível em mediadora mágico-terapêutica e vice-versa, não é uma singularidade deste caso. Trata-se, na realidade, de uma constante antropológica de vários universos cristáos. ${ }^{43}$ Menos comum parece ser a tradução da sua posição simbólica numa linguagem espiritual na qual se condensam, com ressonâncias recíprocas, mas também com contradiçóes, estes vários sentidos. A espiritualidade de Alexandrina pode, assim, compreender-se como a construção de uma interioridade e de formas de expressividade através de uma simbologia mística e devocional que sustenta socialmente tal ambivalência e pluralidade de significados. Por isso, a sua espiritualidade articula-se simultaneamente em termos de sofrimento místico de expiação e na forma de uma interiorização, ou subjetivação, da sua função de mediadora entre mundos:

Sinto em mim as chagas de tal forma abertas que, apesar de serem em mim, parece-me, por dentro delas, passar de um lado para o outro. Mas náo sou só eu; é o mundo inteiro que por elas atravessa, por elas passa, ora por uma ora por outra; são portas francas, pelas quais todos podem passar sem pedir autorização. Todas estas chagas dão passagem para um só caminho, que vai ter à chaga do coraçáo, e da chaga dele, passam a

\footnotetext{
${ }^{40}$ BALASAR, Alexandrina de. Autobiografia. Ditada em 1943 ou 1944. Disponível em: <http://alexandrinabalasar.free.fr/ autobiografia_2.htm>. Acesso em: 21 abr. 2011.

${ }^{41}$ MONTENEGRO, Miguel de. Les bruxos, op. cit. p. 50-58. MONTENEGRO, Miguel de. Un culte thérapeutique au Portugal. Entre Moise et Pharaon. Paris: L’Harmattan, 2006. p. 8-9. José Pedro Paiva identifica a designação de "corpo aberto", com elementos muito similares aos dos "bruxos" estudados por Montenegro, em práticas terapêuticas populares reprimidas pela Inquisição no século XVII. Os "corpos abertos” dos séculos XVII e XVIII existem exlusivamente na zona entre o Minho e o Douro litoral, são sempre mulheres, comunicam com os mortos e podem ser possuídos pelos seus espíritos. PAIVA, José Pedro. Bruxaria e superstição num país sem caça às bruxas. Lisboa: Editorial Notíciais, 1997. passim.

${ }^{42}$ Caderno de notas. 4-3-2011.

43 PORTERFIELD, Amanda. Healing in the history of christianity. Oxford: Oxford University Press, 2005. p. 16-19.
} 
outro Coração, que unido ao seu está. Oh! E com que ansiedade esse Coração recebe a todos quantos para Ele querem ir. ${ }^{44}$

Ecoando a simbólica do "corpo aberto", Alexandrina constrói metaforicamente o seu espaço interior como um canal entre o mundo terreno, contaminado pelo mal, e o mundo sagrado ou divino, simbolizado pelo Sagrado Coraçáo de Jesus. A santa viva vê-se a si mesma como uma ponte entre duas dimensôes que lhe parecem cada vez mais desunidas, a terrena e a celeste. Diríamos que, prolongando os ecos da cultura popular na sua espiritualidade, Alexandrina se reinventou através da linguagem da "mística" e das devoções propostas pelo clero. Essa linguagem permitiu-lhe manter o seu lugar de eleição: a margem entre o mundo terreno e o mundo celeste, entre o mundo dos vivos e o dos mortos. A linguagem da sua interioridade traduz a experiência dessa simbólica da margem.

Neste ponto, é importante olhar mais de perto ao papel da mediação clerical na construção da linguagem de interioridade.

\section{A mediação clerical}

A partir dos anos 1930, a mística de Alexandrina desenvolveu-se no contexto de uma espiritualidade vitimal, associada às devoçóes ao Sagrado Coração e da Eucaristia. Promovida pelos jesuítas e apoiada pelo Vaticano, a partir dos anos 1970, essa espiritualidade valorizava o sacrifício quotidiano pela redenção do mundo, identificado com o corpo místico de Cristo, sofredor pelos "males da modernidade". O sacrifício consubstanciava-se, por um lado, na dádiva penitencial, que podia ser uma dádiva caritativa aos necessitados ou uma expressão pública de "intenções"; e, por outro, na identificação com o Cristo sofredor, através da oração, da mortificaçáo e da comunháo regular. Adaptando-se à capacidade de cada indivíduo, o sacrifício variava habitualmente entre o preenchimento de "bilhetes de intençóes" e pequenas dádivas caritativas. Porém, no limite, poderia tomar a forma de uma dádiva de si próprio em expiação pelos pecados dos homens. Esta espiritualidade, sintetizada na divisa "orar, comungar e sofrer”, foi levada às camadas populares, não só através dos párocos, como de congregaçóes religiosas e de novas formas de organização criadas para a sua difusão: o Apostolado da Oração, a Cruzada Eucarística das Crianças e - associação especificamente feminina — as Marias dos Sacrários-Calvários. ${ }^{45}$

Ora, um dos principais dinamizadores destas organizaçóes em Portugal foi o jesuíta Mariano Pinho, diretor espiritual de Alexandrina desde 1932, assim como de outras mulheres da regiáo. Algumas eram também doentes e, como Alexandrina, associadas ao Apostolado da Oração e ao seu ramo infantil - a Cruzada Eucarística das Crianças —, havendo notícia de jovens dirigidas que, nos anos 1920 e 1930, morreram igualmente com aura de santidade. ${ }^{46}$ Mediado pelo diretor espiritual, o Apostolado da Oração

\footnotetext{
${ }^{44}$ COSTA, Alexandrina Maria da. Sentimentos da alma. Entrada de 1ำ de outubro de 1947, cit. por PASQUALE, Humberto. Beata Alexandrina, op. cit. p. 302.

${ }^{45}$ MARQUES, Tiago Pires. O Apostolado da Oração e a socialização religiosa das camadas populares. In: António Matos Ferreira (Org.). Religião e cidadania: motivaçóes, dinâmicas sociais e protagonismos (séculos XIX e XX). Uma perspectiva ibérica. Portugal e Espanha. Lisboa: Centro de Estudos de História Religiosa, 2011. p. 455-467.

${ }^{46} \mathrm{O}$ movimento devocional a Alexandrina na internet refere os casos de Beatriz Marques Pinheiro e de Blandina Seara, ambas naturais da Póvoa de Varzim e acompanhadas pelo padre Pinho. A primeira, falecida em 1930, aos quinze anos, foi enterrada com o uniforme da Cruzada Eucarística. Disponível em: <http://causapadrepinho.home.sapo.pt/beatriz marques_pinheiro_pt.htm>. Acesso em: 10 maio 2011. Blandina Seara morreu de doença crônica também em 1930, com 22 anos, sendo o seu caso apontado como uma prefiguração do de Alexandrina. Disponível em: <http://causapadrepinho. home.sapo.pt/blandina_seara.htm>. Acesso em: 10 maio 2011. Veja-se ainda o caso semelhante de Carminda, morta nos anos 1930. VIDEIRA, Benjamim. Carminda. Porto: s.n., 1939. Ou ainda o caso, mais conhecido, de Maria da Conceição Pinto da Rocha. ROSA, Maria de Lurdes, Hagiografia e santidade, op. cit. p. 331.
} 
forneceu a Alexandrina um vocabulário e um conjunto de temas e imagens através dos quais a paciente exprimia, de uma forma inteligível no seu círculo local e noutros meios católicos, o seu sofrimento e as suas experiências. Atribuindo um significado religioso e moral à doença penitencial enquanto expiaçáo, esse conjunto de formas dava um sentido religioso à doença. Redentora dos pecados do mundo, a doença de Alexandrina expiava, concretamente, os pecados contra a moralidade, a guerra e as fraquezas dos sacerdotes. ${ }^{47}$

$\mathrm{O}$ trabalho da direção espiritual operou a interiorizaçáo destes temas e imagens. Se tivermos em atenção os documentos biográficos de Alexandrina, tal trabalho consistiu na formalização de uma vida interior pontuada por elementos de ligação à tradição da santidade feminina e da mística cristá, susceptível de transformar a experiência da doença em processo de salvação e de santificação. Um exemplo evidente é o da "morte mística", comparada à de São João da Cruz. ${ }^{48}$ A equiparação da sua experiência a uma situação de morte em vida — sentimento de estar morta, prenúncios de morte, a contemplação da própria morte, prescriçôes para a disposição dos seus restos mortais — pode, como vimos, ser compreendida à luz dos cultos de morte na regiáo. Porém, reelaborado sob o prisma da espiritualidade vitimal, o tema da morte ganhou, em Alexandrina, este novo significado "místico". Alexandrina, identificando-se com Cristo, tornou-se numa figura eucarística — "imolada nos sacrários", como não se cansava de repetir - pela reparação dos pecados do mundo moderno.

Outro exemplo ilustrativo da tradução da linguagem de Alexandrina nas formas da tradição mística é o que nos dá o Padre Pinho ao comentar, na biografia No calvário de Balasar, a utilização da imagem do "foguete". Afirmava o sacerdote: "Às vezes dava-se com a Alexandrina, como remate dessas ânsias, o que Santa Teresa de Jesus chama o voo de espirito e a Alexandrina chama-lhe foguete". Cita então a sua penitente:

Quando sinto muitos desejos de amar a Nosso Senhor, parece-me subir para o Céu, mais rápido do que um foguete (11.7.38). Vou para os braços do meu querido Jesus e da minha querida Mãezinha, perco-me neles. Não tenho mais aflição; acabam-se-me as ânsias de amor: encontrei tudo o que podia encontrar. ${ }^{49}$ (o itálico é do padre Pinho)

Se o idioma religioso local permitiu a Alexandrina socializar um mal sentido como fatalidade de um destino individual, a mediação clerical forneceu um suporte de expressão do mal moral, assim como o guião da sua conversão em salvação espiritual. As suas sombrias alusões à morte não devem, nesta perspectiva, ser interpretadas literalmente, isto é, enquanto expressão, no mesmo grau de intensidade, de um sofrimento moral. Integrando um suporte simbólico densamente codificado, elas constituem um dos elementos de uma performance mística através do qual o seu páthos, à partida socialmente inassimilável, encontrou um veículo de exteriorização e inscrição social. O sofrimento de Alexandrina tornou-se, pois, em certa medida, um sofrimento ritualizado com o qual se identificou - e continua a identificar-se - uma comunidade de devotos. Como nos diz a beata com talento poético, nela há, assim, uma alma que não sofre, mas que não é sua, e outra que sofre, mas de sofrimentos que não são seus:

Sinto que tenho duas almas, uma que sofre e outra que não pode sofrer. A que não sofre não é a minha, e a que sofre não são os meus sofrimentos. A que não sofre é puríssima, parece que tudo vê e que em toda a parte habita e que nada se lhe pode ocultar; é dela a terra, é dela o Céu. A que sofre está em trevas, não é pura, está manchada. Mas não sei como; são duas almas e uma só alma. ${ }^{50}$

\footnotetext{
${ }^{47} \mathrm{O}$ sentido que Alexandrina dá ao seu sofrimento manifesta-se nas suas palavras transcritas, nas biografias e nos testemunhos de pessoas próximas, que recolhi em Balasar.

${ }^{48}$ Disponível em: <alexandrinabalasar.free.fr/sangue_do_cordeiro_01.htm>. Acesso em: 10 maio 2011.

${ }^{49}$ Disponível em: <http://alexandrina.balasar.free.fr/no_calvario_14.htm>. Acesso em: 19 maio 2011.

${ }^{50}$ Sentimentos da alma. 24 out. 1947. Disponível em: <http://alex-balasar.blogspot.com/2011/11/eu-sou-sempre-mesma. html>. Acesso em: 15 fev. 2012.
} 
Em suma, as mediaçôes comunitárias e clericais instalaram Alexandrina no que podemos designar de posição patológica (i.e., a inscrição social de um páthos individual). Pela sua função liminal e significados partilhados de expiação reparadora, essa posição patológica foi, para esta mulher e para os seus devotos, uma experiência de salvação. Veremos, de seguida, que à medicina coube também um papel de relevo na construção desta posição patológica, com a simbólica da margem que lhe é própria, assim como na formulação dos conteúdos da sua experiência interior.

\section{A santidade como fenômeno médico e psiquiátrico}

Alexandrina viveu toda a sua vida adulta rodeada de médicos e sacerdotes. No início, as observaçôes e terapêuticas médicas sucederam-se, sem conseguirem evitar a progressão da doença. No final dos anos 1930, após a manifestação dos êxtases, entraram em cena teólogos e psiquiatras. Alexandrina era conhecida das altas autoridades eclesiásticas pelo menos desde 1935, data em que escreveu ao papa a pedir a consagração do mundo ao Coração de Maria. Em 1937, a Santa Sé enviou uma comissão de teólogos para observar e emitir um parecer sobre a qualidade da sua experiência. Este exame repetiu-se no ano seguinte, seguindo-se-lhe, poucas semanas depois, a observaçáo de um conhecido psiquiatra português, Elísio de Moura. Em 1942, uma primeira relação dos seus êxtases, assinada por um padre dos Missionários do Espírito Santo, veio dar certa amplitude ao caso. Na sequência deste artigo, surgiu uma polêmica teológica na qual foram mobilizadas autoridades da medicina. ${ }^{51}$ Essa polêmica ecoa fortemente nas narrativas autobiográfica e hagiográficas de Alexandrina. Desde logo, os exames clínicos a que foi sujeita são importantes acontecimentos biográficos: precedidos de árduas e por vezes longas viagens, e corporizados em testes e observações penosas e humilhantes, os exames médicos pontuam a Autobiografia, assumindo a natureza de provas físicas e espirituais superadas, e, assim, integrando o calvário espiritual sobre o qual se funda o carisma religioso de Alexandrina.

É importante ter em conta alguns elementos do contexto psiquiátrico da época. Em Portugal, a psiquiatria do início do século XX foi intensamente politizada. Várias personalidades políticas de primeira linha do republicanismo eram psiquiatras ou neurologistas. Miguel Bombarda, Júlio de Matos e Egas Moniz são os mais conhecidos, mas não os únicos. Um dos elementos centrais do programa político do republicanismo era a laicizaçáo da sociedade portuguesa, sendo o clero católico e, em particular, as congregaçóes religiosas, os seus adversários naturais. Particularmente significativo deste contexto foi o conhecido caso Calmon. Em 1900, Rosa Calmon, filha de um diplomata brasileiro em Portugal, viu a sua decisão de entrar na vida religiosa contrariada pelo pai. Dispondo de meios e influência junto da maçonaria, o cônsul mobilizou algumas das grandes personalidades da psiquiatria portuguesa da época, também destacados republicanos, e algumas sumidades internacionais, como Lombroso, com a intenção de que lhe fosse negada a capacidade de autodeterminação. A querela que este caso provocou opôs aqueles que viam em Rosa Calmon um exemplo de vocação religiosa, respondendo a um apelo místico, e os que justificavam a sua religiosidade com o conceito clínico de "histeria". $52 \mathrm{O}$ caso teve grande repercussão midiática, provocou desordens públicas e esteve na origem do encerramento de algumas casas religiosas. Nesse período, surgiram vários trabalhos psiquiátricos patologizantes dos sentimentos e crenças religiosas. Por exemplo, em 1907, o médico e escritor Manuel Laranjeira defendeu,

\footnotetext{
${ }^{51}$ Artigo do padre José Alves Terças, na revista Vida de Cristo, a Paixáo dolorosa, v. V, n. 10, 1942, ao que terá respondido o padre Pinho, com uma publicação no periódico que dirigia, O Mensageiro de Maria, em número de março de 1842. Disponível em: <causapadrepinho.home.sapo.pt/alex_veloso_1.htm>. Acesso em: 10 maio 2011.

${ }^{52}$ GARNEL, Rita. O caso Rosa Calmon: gênero, discurso médico e opinião pública. In: STONE, E.; ABREU, I. S.; SOUSA, A. F. (Org.). Falar de mulheres, história e historiografia. Lisboa: Livros Horizonte, 2008. p. 71-87.
} 
na Escola Médico-Cirúrgica do Porto, uma tese intitulada sugestivamente $A$ doença da santidade. E, antes e depois de Laranjeira, vários psiquiatras republicanos, de António Maria de Sena a Júlio de Matos e Miguel Bombarda, dissertaram também sobre o problema do "delírio religioso", dos estados místicos e da "loucura jesuítica". ${ }^{3}$

A partir dos anos 1920, a psiquiatria tornou-se mais institucional. Abandonando a sua sanha anticlerical e antirreligiosa, a psiquiatria despolitizou-se. Nos anos 1930, já sob o Estado Novo, alguns psiquiatras eminentes eram católicos. Era o caso de Elísio de Moura, primeiro bastonário da Ordem dos Médicos em 1939, professor em Coimbra e figura respeitada pelos seus pares. No entanto, muitos dos conceitos caros à psiquiatria republicana mantiveram-se em uso, ainda que alguns deles - por exemplo, o de "histeria" - sujeitos a críticas ${ }^{54}$. Este contexto médico e psiquiátrico reflete-se plenamente no caso de Alexandrina. Com efeito, os intervenientes do campo médico dividem-se entre crentes e céticos ou ateus, personalidades coadjuvantes e adversárias, destacando-se, entre os primeiros, a figura do médico providencial, Augusto Dias de Azevedo. Atentemos na entrada em cena deste ator decisivo no processo de santificação em vida de Alexandrina. Quando, em 1938, a doente de Balasar começou a viver a paixão de Cristo todas as sextas-feiras, instado pela comissão de teólogos, o seu diretor espiritual procurou médicos católicos que o ajudassem a discernir a natureza dos fenômenos. Teve então lugar o referido exame efetuado por Elísio de Moura, que Alexandrina relata como uma prova particularmente dolorosa e humilhante. Segundo a biografia do jesuíta, esta observação médica saldou-se na negação de um diagnóstico de histeria, cuja possibilidade parece ter sido considerada pelo próprio sacerdote. Porém, o psiquiatra declarou o caso como de "fraude e autossugestão" ${ }_{55} \mathrm{O}$ jesuíta concluía que Elísio de Moura - que, segundo nos informa o sacerdote, também não acreditava em fenômenos como a levitaçáo ou a estigmatizaçáo — nada compreendia de teologia e de mística. Três anos mais tarde, encontrou-se então um médico que, ex-seminarista, tinha também formação em teologia e se interessava pela mística, Manuel Augusto Dias de Azevedo. Dias de Azevedo empenhou-se fortemente no caso de Alexandrina, dedicando-lhe, até a morte desta, uma atenção quotidiana. ${ }^{56}$

Após observar a doente, este médico emitiu um diagnóstico simultaneamente clínico, teológico e psicológico: na perspectiva da medicina, Alexandrina sofria de uma mielite lombar; do ponto de vista teológico e místico, tratava-se de um caso "admirável"; para mais, Alexandrina era inteligente e psiquicamente saudável. Acrescia que "nada, absolutamente nada do que se passa, quer sob o ponto de vista clínico, quer sob o ponto de vista teológico, nos poderá permitir que classifiquemos de naturais ou diabólicos os fenômenos que observamos" ${ }^{57}$ Isto significava, para o médico, que os êxtases tinham uma origem divina. Desejoso de apresentar a prova do fenômeno extraordinário, Dias de Azevedo fez fotografar os êxtases. Aspecto típico da cultura científica positivista da viragem do século XIX para o século XX, a imagem é-nos dada como prova irrefutável de uma objetividade científica, neste caso para confirmar um fenômeno de santidade.

\footnotetext{
${ }^{53}$ Para uma análise desta questão, ver SILVA, Sebastião Nuno. A doença da santidade: concepçôes psicopatológicas do sentimento religioso na comunidade médica primo-republicana. Tese (mestrado em filosofia) — Universidade do Minho, Braga, 2003; e MARQUES, Tiago Pires. Mystique, politique et maladie mentale, op. cit.

${ }^{54}$ Foi o caso de um dos médicos que observou Alexandrina, Henrique Gomes de Araújo. ARAÚJO, Gomes de. Histeria, pithiatismo. Dados teóricos e observaçóes clínicas. Estado actual da questão. Porto: Livraria Moreira, 1919.

${ }^{55}$ Disponível em: <http://causapadrepinho.home.sapo.pt/no_calvario_23.htm>. Acesso em: 10 maio 2011.

${ }^{56}$ O padre Pasquale refere-se-lhe como "um médico enviado por Deus". PASQUALE, Humberto. Beata Alexandrina, op. cit. p. 163 e 166. A importância da acção quotidiana deste médico foi-nos confirmada em entrevista. Caderno de notas, 4-3-2011.

${ }^{57}$ Dias de Azevedo citado em: <alexandrinabalasar.free.fr/no_calvario_23.htm>. Acesso em: 10 maio 2011.
} 


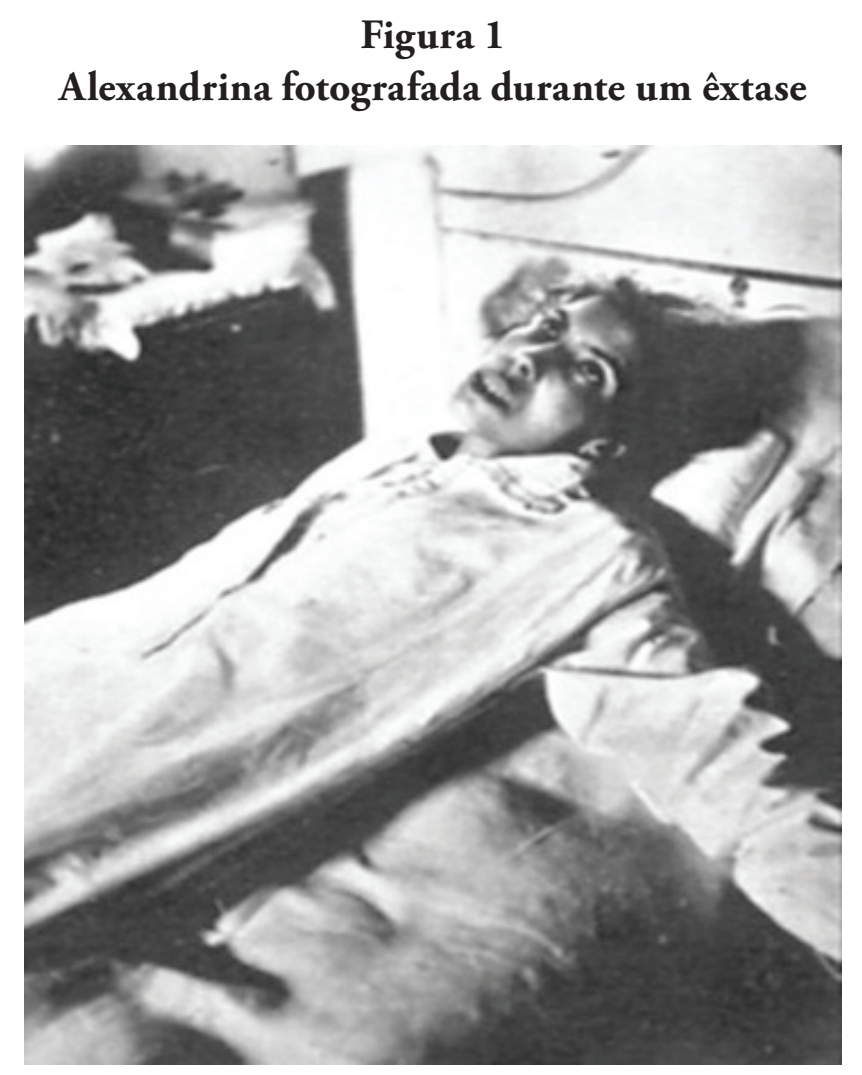

Fonte: <http://alexandrinabalasar.free.fr/album_fotos.htm>. Acesso em: 10 maio 2012. Autor e data desconhecidos (provavelmente início dos anos 1940).

\section{Figura 2 \\ Alexandrina com o médico assistente Manuel Augusto Dias de Azevedo}

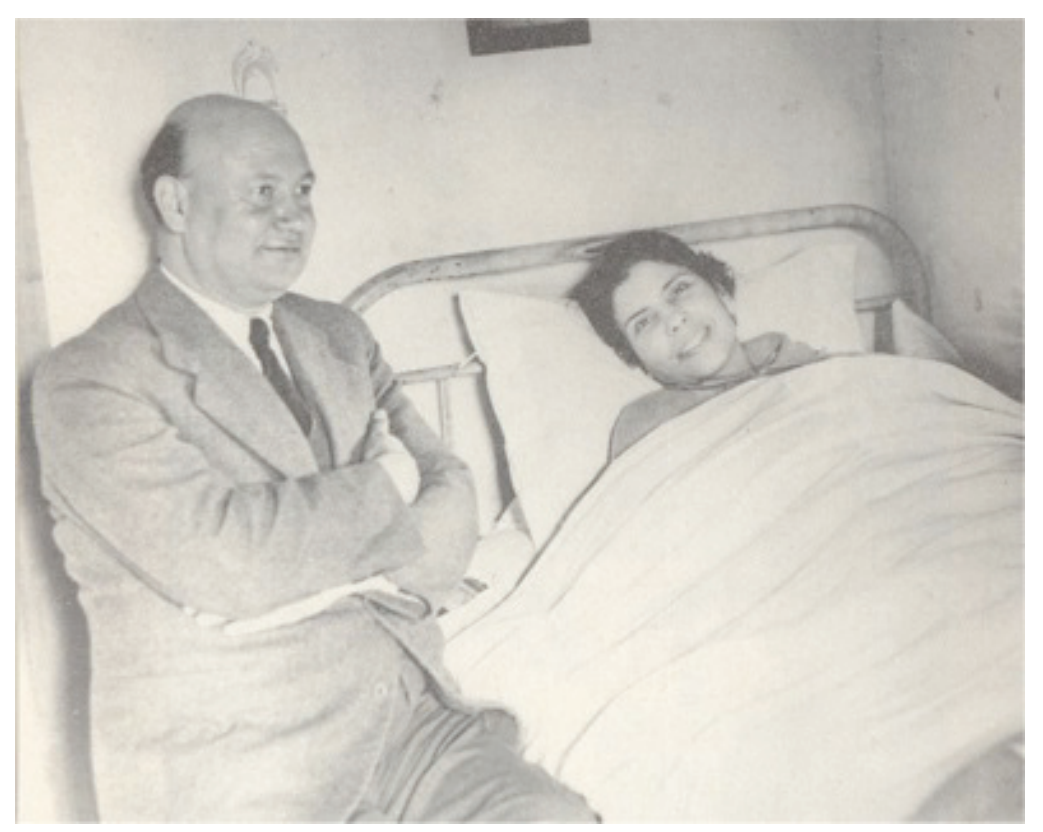

Fonte: <http://alexandrinabalasar.free.fr/album_fotos.htm>. Acesso em: 10 maio 2012. Autor e data desconhecidos (provavelmente início dos anos 1940). 
Foi o médico Dias de Azevedo que conseguiu o internamento hospitalar prolongado de Alexandrina, para comprovação científica do jejum e da anúria. ${ }^{58}$ Entre 10 de junho e 20 de julho de 1943, Alexandrina foi internada no Refúgio da Paralisia Infantil da Foz do Douro, sob supervisão do seu diretor, o então conhecido neurologista Henrique Gomes de Araújo. Segundo Dias de Azevedo, o neurologista estaria convencido de que Alexandrina iludia os que a rodeavam. Mas mais do que desmascarar a falsa santa, Gomes de Araújo queria verificar se o que as hagiografias cristâs descreviam sob a designação de inédia i.e., a possibilidade de viver sem alimentos associada à vida mística e considerada pelos crentes como dom sobrenatural e sinal de santidade - era cientificamente aceitável. A estada no Refúgio assumia, pois, o caráter de uma experiência clínica, comparável às famosas experiências de Charcot, em Paris de finais do século anterior, com mulheres "histéricas" manifestando "êxtases religiosos".

O internamento fez-se mediante a aceitaçáo de duas condiçôes, impostas por Dias de Azevedo: primeiro, que se fizesse também um estudo das faculdades mentais de Alexandrina, declarando-se por escrito se eram ou náo normais; segundo, que a doente náo fosse obrigada a alimentar-se nem lhe fosse injetado nenhum medicamento, a não ser por sua vontade expressa. Na realidade, o internamento, privado de um objetivo terapêutico, visava uma certificação médica do jejum e da normalidade psíquica de Alexandrina.

A observação e a redação do relatório foram ocasião de movimentações e querelas. De acordo com Dias Azevedo, antes de redação do relatório, o padre Agostinho Veloso, também jesuíta, procurou convencer o médico, Gomes Araújo, que Alexandrina era uma "impostora" e o médico um "fanático".

Do internamento resultaram dois relatórios médicos. Um deles era assinado por Gomes de Araújo. Deste relatório, são conhecidos os seguintes excertos:

Linha genealógica da enferma e outros antecedentes: não teve ascendentes alcoólicos nem loucos, mas há algures tuberculosos e cancerosos. (...)

As impressôes clínicas da observação acentuam: Aspecto perfeito à primeira vista, normal intelectiva, afetiva e volitivamente, mas depressa se revela portadora de um equipamento de ideias fixas, estereotipadas e sistematizadas, vivendo e sentindo intensa e sinceramente, sem sombra de mistificação ou impostura, ideias que determinam a abstinência.

E quanto a sintomas fisionômicos e morais: expressão viva, perfeita, meiga, bondosa, acariciante; atitude sincera, despretensiosa, correntia. Nem exotismo nem melifluidades; nem timidez nem exaltamento de voz. Conversa natural, inteligente, subtil.

O relatório concluía:

Concretamente - a observação e a vigilância permitiram verificar estes fatos excepcionais: a doente não comeu, não bebeu, não urinou, não defecou. Citando Charcot, anota-se que a falta de apetite (anorexia mental) é dos acidentes mais graves nos histéricos. Em parte é o caso da Alexandrina. Mas só em parte. É que nela a abstinência é total, acompanhada pela paralisação da função excretora dos rins; quer dizer, nenhumas micçóes, como também nenhumas defecções.

$(\ldots)$

Trata-se duma neurópata. Verificou-se durante 40 dias completa abstinência de alimentos e bebidas, o que leva a crer que tal situaçáo possa ter notável precedência. Durante esse período não defecou nem urinou, o que ultrapassa os casos de aneura (?) conhecidos. A despeito da normal perda de peso, conserva uma frescura e resistência impressionantes. Finalmente, oferece o aspecto dum caso que a Medicina sabe em

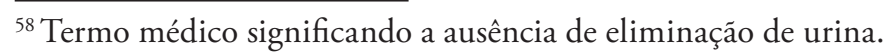


De corpo e alma na margem: Catolicismo, SANtidade e medicina no Norte de Portugal (C. I900 - C. I950)

Tiago Pires Marques

grande parte explicar, mas não deixa contudo de patentear alguns pormenores que, pela sua importância de ordem biológica, tais a duração da abstinência de líquidos e anúria, impóem uma suspensão, aguardando que uma explicação clara faça a necessária luz..$^{9}$

O relatório cumpria, pois, o desígnio pretendido pelo médico assistente: a declaração de que Alexandrina não tinha metabolismo.

O segundo relatório, datado de 26 de julho de 1943, assinado por Dias de Azevedo e por um terceiro médico que acompanhava o caso - Carlos Lima, professor de medicina na Universidade do Porto - atestou o jejum de Alexandrina durante o internamento e confirmou a sua situaçáo de inédia. O relatório certificava ainda das boas faculdades mentais da doente, remetendo para o território da mística a compreensão dos fenômenos verificados às sextas-feiras. ${ }^{60}$

Alexandrina incorporou os elementos clínicos na sua experiência religiosa. Mais do que isso, deu-lhes uma dimensão central: na Autobiografia, o exame clínico é apresentado como o momento culminante do difícil processo de reconhecimento público do caráter sobrenatural das manifestaçóes extraordinárias da sua vida religiosa. Com efeito, o tempo de internamento, prolongado dos trinta dias iniciais estabelecidos para quarenta, adquire um significado religioso: são os mesmos quarenta dias e quarenta noites que Jesus passou em jejum no deserto. A viagem é descrita como uma peripécia iniciática, repleta de provas, e a entrada no Refúgio, durante a qual lhe cobriram o rosto, como uma morte: "Parecia-me estar num caixão", refere. A doente descreve as tentativas terapêuticas como tentaçóes demoníacas: os médicos tentavam persuadi-la a alimentar-se, deixando pratos com "bifes" e outros "petiscos" tentadores na cabeceira da cama. Embora sentindo muitas "saudades da comida", Alexandrina não cedeu. E entretanto, continuou a viver a paixão todas as sextas-feiras, sendo os seus êxtases observados, registados e cronometrados. Como era costume, o médico assistente passava a escrito as "palavras do êxtase". O final dos quarenta dias de provação é relatado por Alexandrina como um momento de reconciliaçáo com a equipe médica e de reconhecimento público. Então visitada "talvez por mil e quinhentas pessoas”, terá sido necessária intervenção policial para manter a ordem. A saída do Refúgio é contada como um momento de glória: já na automaca, lançam-lhe flores e perfume. Recolhe em silêncio e meditação à casa materna, sublinhando que não sentiu "vaidade". ${ }^{61}$

A polêmica sobre a natureza mística ou patológica de Alexandrina prolongou-se, nomeadamente com uma nova publicação de Agostinho Veloso na Brotéria, em 1947, tendo como característica assinalável o fato de os sacerdotes mobilizarem categorias psiquiátricas, tais como os conceitos de "psicose do maravilhoso" e "histeria". ${ }^{62}$ Porém, para Alexandrina, como para os médicos católicos que Dias de Azevedo conseguiu mobilizar, o internamento constituiu uma validação da sua experiência mística, fornecendo as provas necessárias da intervenção sobrenatural. Em 1948, Jesus teria dito a Alexandrina: "Sou o teu médico divino. Preparo-te para o martírio com a minha medicina" ${ }^{63} \mathrm{O}$ médico divino saía, pois, vitorioso.

\footnotetext{
${ }^{59}$ Relatório médico do internamento de Alexandrina no Refúgio da Foz do Douro, citado em: <jejumalexandrina.blogspot. com>. Acesso em: 10 maio 2011. E parcialmente reproduzido em: ARAÚJO, Gomes de. Um notável caso de abstinência e de anúria. In: PASQUALE, Humberto. Beata Alexandrina, op. cit. p. 164 e 196.

${ }^{60}$ Carlos Alberto de Lima e Manuel Augusto Dias de Azevedo. Relatório datado de 26-7-1943. In: PASQUALE, Humberto. Beata Alexandrina, op. cit. p. 196-197. Esta fonte cita ainda um terceiro relatório, assinado por um coletivo de médicos brasileiros, aos quais foram enviados, pelo padre Mariano Pinho, entretanto estabelecido no Brasil, os relatórios dos médicos portugueses. Ibidem, p. 199-200.

${ }^{61}$ Autobiografia. Disponível em: <http://alexandrinabalasar.free.fr/autobiografia_2.htm>. Acesso em: 10 maio 2011.

${ }^{62}$ VELOSO, Agostinho. Mística e jornalismo. In: Brotéria, v. XLIV, p. 5-20, p. 5, jan. 1947.

${ }^{63}$ Colóquios entre Jesus e Alexandrina, citados por PASQUALE, Humberto, Beata Alexandrina, op. cit. p. 303.
} 
Nesta polêmica cruzada entre médicos e homens da Igreja, nos anos 1940 e 1950 assistiu-se, assim, a uma singular inversão das posiçôes do início do século: a autoridade médica sustentava o caráter religioso do fenômeno observado, enquanto algumas autoridades religiosas defendiam, com recurso a termos psiquiátricos, o seu caráter patológico. Aspecto assinalável, mas não uma singularidade absoluta deste caso, ${ }^{64}$ a medicina e a linguagem médica participaram ativamente na santificação de Alexandrina.

\section{Conclusão: um processo plural de estruturação da experiência religiosa}

A experiência religiosa de Alexandrina formou-se no interior de uma configuraçáo de elementos heterogêneos e manifestou-se num idioma plural, simultaneamente popular, clerical e médico. Figura liminal e agente mágico-terapêutico para a população local, Alexandrina construiu uma interpretação da sua doença no vocabulário místico da espiritualidade vitimal e de reparação da segunda metade do século XIX e primeiras décadas do século XX. Com uma coloração afetiva característica da oralidade feminina da sua região, esse vocabulário transporta também a marca do estatuto e da fragilidade sociais de Alexandrina.

Este caso místico é indissociável de uma história e de um contexto local. Porém, ele reflete, na mesma medida, elementos de um universo religioso que o ultrapassa largamente. Neste sentido, a história de Alexandrina contrasta não só com a sorte de personalidades religiosas recolhidas nos hospitais psiquiátricos das grandes cidades, mas também com personalidades místicas de vida claustral suas contemporâneas, onde se aplicava, de forma mais incisiva, a grelha teológica e psiquiátrica moderna, assente nas noçôes de "delírio", "histeria" e "psicastenia". ${ }^{65}$ Observada juntamente com outros casos conhecidos comportando elementos idênticos - em Portugal, a Santinha da Arrifana, Maria da Conceição Mendes Horta (conhecida como "Santa da Ladeira"); ${ }^{66}$ fora de Portugal, Marthe Robin e Therese Neumann, entre muitos outros —, a história de Alexandrina permite formular a seguinte hipótese geral: disciplinando-se nos conventos, tornada mais simbólica ou mitigada numa "pequena via mística", ${ }^{67}$ a tradição extática da mística feminina ressurgiu nos meios rurais e nas pequenas cidades de província numa forma vernacular, ${ }^{68}$ isto é, integrando práticas e espiritualidades formadas na interação entre as camadas populares e os agentes clericais.

Podemos, enfim, desenvolver esta hipótese nos seguintes termos: pelo menos neste caso - mas possivelmente também noutros - a mística vernacular criou um dispositivo clínico ad hoc que, para além de exercer uma função de credibilização científica, se revelou estruturante da própria experiência religiosa. Com efeito, as condiçôes do internamento de Alexandrina indiciam uma conjuntura psi-

\footnotetext{
${ }^{64}$ Sobre a colaboração entre autoridades eclesiásticas e médicos em ambientes devocionais no período contemporâneo, ver, por exemplo, PORTERFIELD, Amanda. Healing in the history of Christianity, op. cit. p. 180-184; e GUILLEMAIN, Hervé. Diriger les consciences, guérir les âmes. Une histoire comparée des pratiques thérapeutiques et religieuses (18301939). Paris: Éditions la Découverte, 2006. p. 230-236.

${ }^{65}$ CHARUTY, Giordana. Le couvent des fous. L'internement et ses usages en Languedoc aux XIXe et XXe siècles. Paris: Flammarion, 1985. p. 333.

${ }^{66}$ ROSA, Maria de Lurdes. Hagiografia e santidade, op. cit. p. 331-337.

${ }^{67}$ Expressão consagrada para referir a via mística claustral de Santa Teresa de Lisieux, no final do século XIX, assente numa espiritualidade devocional de pequenas açóes reparadoras, em contraste com a mística expressiva e barroca popularizada por Santa Teresa de Ávila (século XVI) e Santa Maria Margarida Alacoque (século XVII). MAÎTRE, Jacques. Thérèse de Lisieux. L’Orpheline de la Bérésina (1873-1897). Paris: Les Éditions du Cerf, 1995. p. 67-68.

${ }^{68}$ Segundo Nathan Mitchell, a Igreja pós-tridentina procurou renovar a cristandade através de novas formas de integração comunitária e de solidariedade social construídas largamente sobre formas e símbolos vernaculares. MITCHELL, Nathan D. The mystery of the Rosary. Marian devotion and the reinvention of Catholicism. Nova York; Londres: New York University Press, 2009. p. 128-129.
} 
quiátrica com elementos distintos daquela que observamos para as primeiras décadas do século $\mathrm{XX}$, muito marcada pelas posiçóes antirreligiosas e anticlericais. Porém, tal conjuntura incluiu também elementos caraterísticos da psiquiatria positivista fin-de-siècle. Tal como nas experiências de Charcot com as pacientes "histéricas", a intervenção da medicina, que se pretendia demonstrativa mais do que terapêutica, contribuiu para a manutenção da paciente na sua posição patológica. Neste caso, ao confirmar o jejum, a medicina reatualizou o tópico da inédia, central na tradição da mística feminina cristá. A observação da beata de Balasar ilustra, pois, um caso de sobreposição entre um tópico e uma prática religiosas - a inédia, ou anorexia sagrada - e um objeto de investigação científica, a anorexia nervosa. Tal observação deu a ver, qual revelador fotográfico - e mesmo através da imagem fotográfica e do registo de imagens em filme ${ }^{69}$ —, uma forma particular do corpo místico: não o da estigmatização ou da visão beatífica, mas o do êxtase e do jejum, os significantes principais do carisma desta personalidade religiosa.

\footnotetext{
${ }^{69}$ Segundo testemunhos locais, os êxtases de Alexandrina foram filmados, sendo o filme regularmente exibido à população em dias de celebração da beata.
} 